\title{
Economic Impact of Microhydro Power Project in Jambi Province, Indonesia
}

\author{
Rizal Bahtiar ${ }^{1}$, A. Faroby Falatehan ${ }^{1}$, Deffi Ayu Puspito Sari², Suyono Thamrin ${ }^{3}$ \\ \{affalatehan@gmail.com,deffi.sari@bakrie.ac.id, suyono.thamrin@idu.ac.id\} \\ ${ }^{I}$ Department of Resource and Environmental Economics, Faculty of Economics and Management, \\ Bogor Agricultural University \\ ${ }^{2}$ Environmental Engineering Program Study, Universitas Bakrie \\ ${ }^{3}$ Defense Industry Program Study, Indonesia Defense University
}

\begin{abstract}
The objective of this study is to analyse the economic impact of a micro-hydro plant in Jambi to society around this micro-hydro plant. This study was conducted in Jambi Province Indonesia at Merangin and Mamasa Regency, Indonesia from January December 2015. Primary data was collected by interview and observation. Analysis of Productivity Approach and Opportunity Cost was done to reveal the economic impact of a micro-hydro plant in Sungai Tenang District. From the result, micro hydropower has considerable benefit in Sungai Tenang District; total value of the benefits obtained is IDR 77.83 billion per year. Communities' revenue through the economic enterprise that does not divert the function of forest needs to be improved. So the electrical energy independence in the community can be created. To fulfil the independence management of micro hydropower, economic treatment is needed especially in increasing of revenue. Micro hydro power also has a positive impact on the forest conservation on upper river area. Micro hydro power improvement must coincide with the non-timber forest revenue increasing program or other businesses that do not divert the function of the forest.
\end{abstract}

Keywords: green energy, less carbon development, opportunity cost, productivity approach, remote area power supply.

\section{Introduction}

One way to reduce the dependency on fossil fuel is by increasing the renewable energy production capabilities. A micro hydropower plant can use a reaction or impulse turbine depending on the available resource. It is very important to consider the short-term economic feasibility of renewable energy resources for developing countries. Among all renewable energy sources, hydroelectricity is the most economical and reliable source (Erinofiardi et al, 2016). The first turbine in Indonesia was installed in 1885 in West Java. At this time the turbines were providing shaft power to tea rollers and other machinery in the tea factory but not directly driving generators. Later, with advancing turbine and generator technology, hydroelectric power plants were built. Micro-hydro has the priority development due to environmental concern, relatively low cost and its huge potential in Indonesia (approximately up to $75,000 \mathrm{MW}$ ). Micro hydro is a priority for diesel fuel substitution for electricity generation in the remote area and for rural electrification. One of the advantages of micro hydro is reducing the CO2 emission by replacing diesel power. In Indonesia, only around 9\% micro-hydro potential has been exploited in the form of a large-scale power plant and smallscale power plant. Particularly in small-scale, application of micro hydro power plant in Indonesia was started in 2005 as $0.45 \mathrm{MW}$. Development of this hydropower plant is not 
significant at the beginning, which was became $0.55 \mathrm{MW}$ in 2006 and 2007, increased to 0.69 MW during 2008 to 2010 (Kencono\&Dwinugroho 2015).

Indonesia government has a strategy to use renewable energy and adding cumulative capacity $20 \mathrm{MW}$ from hydro power plant in East region of Indonesia and also from mini hydro power generation, $21 \mathrm{MW}$ in Java-Bali, $11 \mathrm{MW}$ in Sumatra, and $18 \mathrm{MW}$ for Eastern part of Indonesia respectively. However, there was no hydro power plant built until August 2015 yet. Some construction of hydro power plant 13.9 MW in Eastern part of Indonesia namely are Siteba 3 x $2.5 \mathrm{MW}$, Tombolo Pao $2 \mathrm{MW}$, Taludaa $3 \mathrm{MW}$, Segara $1 \mathrm{MW}$ and micro hydro Lokomboro 0.4 MW (Kencono et al 2015).

Sungai Tenang District is one of district located on Merangin Regency, Jambi Province. There are 12 villages in Sungai Tenang District; with total population is 9231 or 2308 head of family. The income of the population derived from the agricultural sector with the main crops grown are coffee, cinnamon, and patchouli, both commercial and subsistence farmers are present in the district (Falatehan, 2017). Most of the poor in rural area depends on agriculture (Deffi, A.P.S., 2010., Sari, D.A.P., 2016). Increasing their access to basic needs will improve their capability (Sari, D.A.P., 2012). Electricity has become one basic need for improving economic condition of villagers.

Sungai Tenang District is a district that has no supply of electricity from State Electricity Company; the district is in mountainous area with poor road access and power lines installation. However, the potential of river water resources that can be converted into electricity is a great opportunity, this opportunity is exploited by Merangin Regency Government to provide micro hydro power plant (MHP) of 30 Kilowatts which can supply electricity at night from 18:00 to 22:00. The small power generated based on the capacity of the generator at Sungai Jangkat, which is the location choose for Green Prosperity Project that can generate $2 \mathrm{MW}$ and $1 \mathrm{MW}$ for a total of $3 \mathrm{MW}$ (based on the calculation of potential energy for electricity by the Ministry of Energy and Mineral Resources-ESDM Ministry, Merangin Regency) (Yanto, 2016).

The objective of this study is to analyse the economic impact of a micro hydro plant in Jambi to society around this micro-hydro plant

\section{Micro Hydro Power}

Hydro-electricity is fundamentally the combination of water flow and vertical drop. Vertical drop creates pressure, and the continuous flow of water in a hydro system gives us an ongoing source of pressurized liquid energy. Pressurized, flowing water is a very dense resource, and hydro-electric systems convert a very large percentage of the available energy into electricity because the resource is captive in a pipe or flume (Figure 1). 


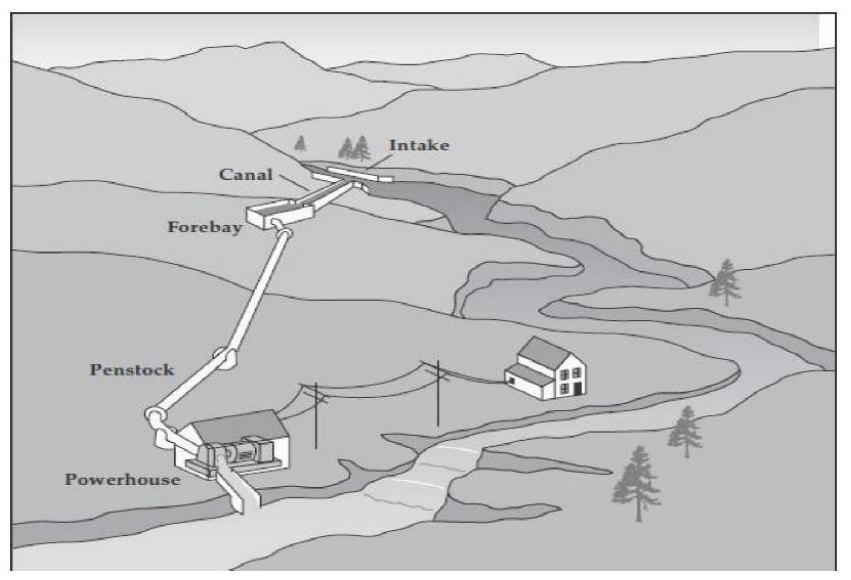

Fig. 1. Model of Micro Hydro

According to US Department of Energy (2001), hydropower systems use the energy in flowing water to produce electricity or mechanical energy. Although there are several ways to harness the moving water to produce energy, run-of-the-river systems, which do not require large storage reservoirs, are often used for micro-hydro, and sometimes for small-scale hydro, projects. For run-of-the-river hydro projects, a portion of a river's water is diverted to a channel, pipeline, or pressurized pipeline (penstock) that delivers it to a waterwheel or turbine. The moving water rotates the wheel or turbine, which spins a shaft. The motion of the shaft can be used for mechanical processes, such as pumping water, or it can be used to power an alternator or generator to generate electricity.

Access to flowing water is needed to build a small hydropower system. A sufficient quantity of falling water must be available, which means that usually hilly or mountainous sites are best. Next, it is required to determine the amount of power that can be obtained from the flowing water on a site. The power available at any instant is the product of flow volume and head. The units of power can be put in terms of watts, kilowatts, or megawatts (Tenkir, 2014). In overall of 21 species plants belonging to 16 families were collected, identified and reviewed. The plants were listed and discussed according to collected information from interviewed and literature review. The lists of plant were arranged by family, botanical name, native name (EN: English name, SN: Siamese name/ MN: Malay name), physical description and previously studied uses of the plant's parts.

\section{Methodology}

This study is conducted in Jambi Province Indonesia at Merangin and MamasaRegency, Sungai Tenang District, Indonesia. The study conducted from January - December 2015. The concept of opportunity cost is one of the most important ideas in economics. Opportunity cost is the best alternative sacrificed for a chosen alternative (Tucker 2010). In other stated, it is the cost of not choosing the next best alternative. The principle states that some highly valued opportunity must be forgone in all economic decisions. The actual good or use of time the cost of the opportunity cost (Ellen, 2016). In this study, the opportunity cost is used to analyze economic value of energy used by people around the micro hydropower plant. There is some analysis for fuel efficiency by using the generator, Firewood Efficiency for Cooking, ironing, stores revenue increasing, and fuel efficiency workshop and fuel efficiency in school. 
This approach is used to examine the benefits of micro hydropower. This approach is used to analyze the economic value of fuel efficiency by using Coffee Paring Machine, Cinnamon Skin Peeling Time Efficiency and handicraft increasing revenue.

New productivity is productivity after the change in the technology of production. The formula of productivity approach is used change in productivity, the formula is.

\section{Results And Discussion}

Micro hydro power establishment has considerable benefits for society of Sungai Tenang District. Nowadays people still use diesel, kerosene lamps (oil lamps), and lighting firewood in the district. The construction of microhydro power with a large capacity and capable to supply electricity (up to 24-hours) in Sungai Tenang District provides the following benefits:

Table 1. Economic benefits of Micro Hydro Power Plant in Sungai Tenang District.

\begin{tabular}{cllrl}
\hline No. & \multicolumn{1}{c}{ Benefits } & \multicolumn{1}{c}{ Method } & Amount & Units \\
\hline 1 & $\begin{array}{l}\text { Economic value of fuel efficiency by using } \\
\text { Generator }\end{array}$ & Opportunity Cost & $4,204,800,000$ & IDR/Year \\
\hline 2 & $\begin{array}{l}\text { Economic value of fuel efficiency by using } \\
\text { Coffee Paring Machine }\end{array}$ & $\begin{array}{l}\text { Productivity } \\
\text { Approach }\end{array}$ & $30,688,000$ & IDR/Year \\
\hline 3 & $\begin{array}{l}\text { Economic value of Kerosene Efficiency by } \\
\text { using oil lamp }\end{array}$ & Opportunity Cost & $6,318,150,000$ & IDR/Year \\
\hline 4 & $\begin{array}{l}\text { Economic Value of Firewood Efficiency for } \\
\text { Cooking }\end{array}$ & Opportunity Cost & $16,848,400,000$ & IDR/Year \\
\hline 5 & Economic Value of ironing efficiency cost & Opportunity Cost & $1,661,760,000$ & IDR/Year \\
\hline 6 & $\begin{array}{l}\text { Economic Value of Cinnamon Skin Peeling } \\
\text { Time Efficiency }\end{array}$ & $\begin{array}{l}\text { Productivity } \\
\text { Approach }\end{array}$ & $41,539,500,000$ & IDR/Year \\
\hline 7 & Economic value of stores revenue increasing & Opportunity Cost & $4,950,000,000$ & IDR/Year \\
\hline 8 & Economic value of workshop fuel efficiency & Opportunity Cost & $887,040,000$ & IDR/Year \\
\hline 9 & $\begin{array}{l}\text { Economic value of handicraft revenue } \\
\text { increasing }\end{array}$ & $\begin{array}{l}\text { Productivity } \\
\text { Approach }\end{array}$ & $1,320,000,000$ & IDR/Year \\
\hline 10 & Economic value of fuel efficiency in school & Opportunity Cost & $73,200,000$ & IDR/Year \\
\hline & $\quad$ Value of benefit micro hydro power overall & $77,833,538,000$ & IDR/Year \\
\hline
\end{tabular}

Based on the interview with a village secretary of RantauSuli Village and the villagers, the micro hydropower has been able to supply electricity for 24 hours, and then the micro hydropower is IDR 77.83 Billion per year. The value consists of fuel efficiency of the use of household generators by IDR 4.20 Billion. The value is obtained from the use of fuel as much as 2 litres/day, at a price of IDR 8000/litre. The fuel efficiency value of the coffee paring machine is IDR 30.69 million per year. Coffee plantation in Sungai Tenang District with an area of 959 ha yield 1 ton in a year, if the price of unpeeled coffee sold for IDR $8000 / \mathrm{kg}$ and peeled coffee for IDR $16.000 / \mathrm{kg}$, there is a different benefit by IDR $8.000 / \mathrm{kg}$. Limitations of coffee paring machine encourage people to sell unpeeled coffee.

The use of kerosene lamps is still continuing, it used when generator had run out of fuel. Each household has 5-6 kerosene lamps for lighting requirements and needs as much as 1 litre of kerosene at a price IDR 7500 / litre. Based on the data, the fuel efficiency value of the kerosene lamps is IDR 6.32 billion per year. Nowadays, people still using firewood for cooking. The unavailability of gas encourages people to use firewood if the gas price per 12 $\mathrm{kg}$ is IDR 170,000 / tube. Firewood obtained from the peeled cinnamon tree and out of the branches in the forest. For cooking in 40 days, 1 pickup of wood with the price IDR 800,000 / pick up is needed. Based on these data it can be calculated the efficiency of firewood for cooking is IDR 16.85 Billion per year. 
When ironing the clothes, villagers are still using the charcoal iron tool. Based on the interviews with the housewives, it earns as much as 2 bunches of charcoal for IDR $7500 /$ bunches in a week. So that the efficiency by switching charcoal irons to electric one will get efficiency values of IDR 1.66 billion per year. Demand for electricity is also beneficial in stripping the epidermis of cinnamon. Currently, cinnamon epidermis cleansing use only manual tools such as knives specially designed for cinnamon, the use of such tools the manually stripping of a bunch of cinnamon (around $60 \mathrm{~kg} / \mathrm{bunch}$ ) takes one night. Villagers said stripping the epidermis of cinnamon can be peeled with an electric knife, using such tools can do 1 bunch within 1 hour. If the salary IDR 50000 per night and 60\% villagers did it, so the efficiency by using an electrical knife is IDR 41.45 billion. The electric availability is needed by Sungai TenangDistrict residents, especially for those who have a business. It is felt for those who have a grocery store, where it is open to the store in the morning until the early evening (8:00 until 17:00). Currently, the average store income is IDR 8,000,000/ month. The store enterprises on Sungai Tenang District are estimated there are 300 units. If the electricity exists for 24 hours, then they can open up the shop until 21:00 or 12 hours/day. Based on these data the revenue is estimated at IDR 4.95 billion / year. Motorcycle workshop business also so desperately need electricity existence, this time in the District consists of 84 units with the use of diesel to meet the needs for lighting and workshop appliance. Every day the need for diesel fuel as much as 4 litres at a price IDR 8.000 / litre, if they worked in a year by 11 months, the value of the fuel efficiency of a business workshop by IDR 887, 04 million / year.

Increasing of villagers' productivity by the results of handicrafts; if there were 600 housewives who crafting and produce income IDR 50,000 per day and free time to work 1 day a week, while only 11 months of the year, then the value of the productivity of mothers in Sungai Tenang District because electricity is IDR 1.32 Billion / year. Another sector that desperately needs electricity is education, where there are 3 schools in Sungai Tenang District that requires fuel every day an average of 10 litre/day at IDR 8,000 / litre of prices. If the school operates effectively 305 days gives IDR 73.2 million / year of fuel efficiency.

Electricity needs in the community are very important, especially in increasing productivity and ease of working. However, based on interviews with several community leaders, the condition of most people in the Calm River District was classified to less capable livelihood as agricultural or plantation laboratory. Currently, the cost of electricity per person is IDR 30,000 per month in electricity usage that can supply electricity from 18:00 to 22:00. The minimum power requirement per household in the following table 2 :

Table 2. Minimum Electricity Requirement of Household

\begin{tabular}{clrc}
\hline No & \multicolumn{1}{c}{ Activity requires electricity } & Electrical needs & Units \\
\hline 1 & 1 unit 350 watt of iron, 2 hours a day & 0.7 & KWh \\
\hline 2 & 1 unit 150 watt of water pump, 3 hours a day & 0.45 & KWh \\
\hline 3 & 1 unit 100 watt of fridge, 6 hours a day & 0.6 & KWh \\
\hline 4 & 1 unit 110 watt of 20" TV set, 6 hours a day & 0.66 & KWh \\
\hline 5 & 1 unit 300 watt of rice cooker, 2 hours a day & 0.6 & KWh \\
\hline 6 & 6 unit 20 watt of energy-saving lamp, 6 hours a day & 0.72 & KWh \\
\hline 7 & 4 unit 10 watt of energy-saving lamp, 6 hours a day & 0.24 & KWh \\
\hline The amount of electrical needs a day & 3.91 & KWh \\
\hline The amount of electrical needs per month 3,91 kWh x 30 days & 117.3 & KWh \\
\hline
\end{tabular}

Based on The State Electricity Company (PLN), the electricity price is IDR 1,342 per KWh, then each family will pay for IDR 157,417 / month. This bill becomes the basis of calculation of electricity use of villagers (willingness to pay). Several families seem to not pay for it so that the installment of micro hydropower plan will give great help to the society. 
However, the inability of the public was also seen when the micro hydropower generator of Merangin Regency Government was broken, the villagers are not able to repair or replace the damaged generator with a new one because the price is very expensive.

\section{Conclusion}

Micro-hydropower has considerable benefit in Sungai Tenang District; the total value of the benefits is IDR 77.83 billion per year. Communities' revenue through the economic enterprise that does not divert the function of forest needs to be improved. So the electrical energy independence in the community can be created. To fulfil the independence management of micro hydropower, economic treatment is needed especially in increasing of revenue. Micro hydro power also has a positive impact on the forest conservation on upper river area. Micro hydro power improvement must coincide with the non-timber forest revenue growing program or other businesses that do not divert the function of the forest.

\section{References}

[1] Deffi, A. P. S. (2010). Changes in the Upland Crop Farm Economy in INDONESIA. TOHOKU JOURNAL OF RURAL ECONOMICS, 28(2), 30-37.

[2] Ellen KrohnAasg and Henrik Roti.(2016). Opportunity-cost-pricing of reserves for a simple hydropower system. European Energy Market (EEM). ieeexplore.ieee.org.

[3] Erinofiardi, PriteshGokhale , Abhijit Date , Aliakbar Akbar zadeh, Putra Bismantolo , Ahmad Fauzan Suryono, Afdhal Kurniawan Mainil, Agus Nuramal. (2016). A review on micro hydropower in Indonesia .1st International Conference on Energy and Power, ICEP2016, 14-16 December 2016, RMIT University, Melbourne, Australia Energy Procedia 110 ( 2017 ) 316 321.

[4] Falatehan, A. F., Syaukat, Y., Raswatie, F. D., \& Sari, D. A. P. (2017).Planting and Consumption Patterns of Upland Rice Farmer in Indonesia. ADRI International Journal Of Agriculture, 1(1).

[5] Kencono, Agung Wahyu and Dwi nugroho MP.(2015). Handbook of energy and economic statistics of Indonesia 2015.Ministry of Energy and Mineral Resources Republik of Indonesia, Jakarta.

[6] Kencono, Agung Wahyu Kencono; SugengMujianto; Aang Darmawan.(2015). Perkembangan penyediaan dan pemanfaatan migas batubara energy baru terbarukan dan listrik. Pusat data dan teknologi informasi Kementerian ESDM Jakarta.

[7] Sari, D. A. P., \& Kawashima, S. (2016). Poverty Mapping And Poverty Analysis In Indonesia. Jurnal Agro Ekonomi, 28(1), 95-111.

[8] Sari, D. A. P. (2012).education, health, and basic needs: Increasing capabilities to escape poverty. Three Reasons Why We Should Study Human Security, 1, 8-24.

[9] Tenkir, Ermias. (2014). Financial And Economic Analysis of Small Hydropower in Ethiopia. Thesis.The school of Graduate Studies of Addis Ababa Institute of Technology. Addis Ababa.

[10] Tucker, Irvin B. (2010). Microeconomics for Today.Sixth Edition.South WesterCengage Learning.

[11] U.S. Department of Energy (U.S. DOE).(2001). Small Hydropower Systems: www.nrel.gov/docs/fy01osti/29065.pdf.

[12] Yanto, Bambang Edy Laporan. (2016). Feasibility Study (FS) dan Detail Engineering Design (DED) PLTMH (Pembangkit Listrik Tenaga Mikro Hidro) yang dibangun di Merangin Provinsi Jambi. CV. Bangun Cipta Persada 